\title{
FINANCIAL STATEMENT FRAUD LIKELIHOOD DETERMINANTS IN MICRO FINANCIAL INSTITUTIONS IN CAMEROON
}

\author{
Samuel Tanjeh Mukah' \\ ${ }^{1}$ Department of Accountancy, Faculty of Economics and Management Sciences, \\ University of Bamenda, Cameroon.
}

Tel: (237)677383633 e-mail: sammukah2003@yahoo.com

\begin{abstract}
The state of health of an organisation is scientifically diagnosed from its financial statements. Where the financial statements' quality is compromised, decisions taken based on such fraud infected financial statements could lead to devastating consequences. Many consumers of micro-financial services, sometimes express worries about the quality of financial reports issued. These worries are further compounded by empirical studies which disclose that financial statement fraud though the least common, is the most costly to an organisation. As a consequence this study sets out to investigate the financial statement fraud likelihood determinants prevalent in micro financial institutions in Cameroon. Data was collected through a survey, analysed and regressed. The empirical results revealed that fraudulent audit confirmations, falsification of financial amounts, alteration of accounting records, misrepresentations, and improper capitalisation of expenses are the main likelihood determinants. Although financial statement fraud cannot be completely eradicated given that they are perpetuated by human beings who themselves are imperfect, it can be significantly mitigated when micro financial institutions become conscious of the events or conditions that motivate the commission of financial statement fraud. Micro financial institutions are encouraged to create enabling environment for the stagnation of these elements by strengthening the internal control systems of assets, liabilities, expenses, and revenues. Independent audits be carried out irregularly, perpetrators of fraud held responsible, and employees treated decently and fairly. Management should introduce financial management ethics to employees and be very sensitive to behavioural red flags.
\end{abstract}

KEYWORDS: Fraud, financial statement, micro-financial institutions, fraudulent audit confirmation, falsification, bid rigging, misrepresentation, improper capitalisation of expenses.

\section{INTRODUCTION}

Costly scandals concerning Enron, WorldCom, Global Crossing and Tyco have significantly increased public awareness about the devastating effects of fraud on business organisations. Fraud is a recurrent and disquieting problem encountered by organisations of both the public and private sectors in Cameroon. Mirriam-Webster Dictionary defines fraud as deceit or trickery that leads to intentional perversion of truth in order to induce another to part with something of value or to surrender a legal right. American Institute of Certified Public Accountants (AICPA) describe fraud as an intentional false representation or concealment of a material fact for the purpose of inducing another to act upon it to his or her injury. The International Standard on Auditing (ISA) 240, "The Auditor's Responsibility to Consider Fraud in an Audit of Financial Statements," defines fraud as an intentional act by one or more 
individuals among management, those charged with governance, employees, or third parties, involving the use of deception to obtain an unjust or illegal advantage.

Whatever viewpoint is given to fraud, fraud connotes a calculated distortion of financial statements for the benefit of the committer at the expense of a victim, usually someone, some organisation, or even a public. According to the auditing guidelines, fraud is used only to refer to irregularities involving the use of criminal deception to obtain an unjust or illegal advantage. For example, deliberate inflation of stock value in order to impress an entity to continue to provide credit to the organisation. This is corroborated by the American Institute of Certified Public Accountants, as it distinguishes fraud from error based on whether the action was intentional or unintentional. That is, where the irregularities carry criminal intent they become fraud.

Identification of effective methods of perceiving fraud likelihood is an important precondition for treating any type of fraud, given that by its nature fraud does not present itself to being scientifically observed or measured in an accurate manner, (McNeil 1992). Making reference to ACFE, Dalnial et al. 2014 identify one of the primary characteristics of fraud to be its clandestine, or hidden nature because almost all fraud involves an attempt to conceal the crime.

The ISA 240 requires auditors to be more concerned with two types of fraud namely: misstatements arising from fraudulent financial reporting, and misstatements arising from the misappropriation of assets. Financial fraud may still take place even when an organisation is regularly audited. The general public may be greatly disappointed to learn this, given that they largely perceive an audit as an exercise to detect fraud. Auditor responsibility for fraud detection was summarised by the 1896 Lord Justice Lopes' ruling in the United Kingdom, given in the Kingston Cotton Mill case: 'An auditor is not bound to be a detective, or ... to approach his work with suspicion, or with a foregone conclusion that there is something wrong. He is a watchdog, not a bloodhound.' The auditor is therefore entitled to place reliance on the representation of trusted officials of the organisation he is auditing.

However, the auditing requirements have evolved with the standard of care placed upon auditors in the Kingston Cotton Mill case (1896). Subsequent court judgements have gone beyond relying on representations by trusted managers of the organisation, to physical and personal inspection (Thomas Gerrard and Sons Limited case, 1967). The auditor then has the duty to state whether the accounts give a true and fair view and comply with the relevant legislation. The Public Company Accounting Oversight Board (PCAOB, 2017) defines the fair presentation of financial statements in conformity with generally accepted accounting principles as an implicit and integral part of management's responsibility. However, an independent auditor may make suggestions about the form or content of the financial statements or drafts them, in whole or in part, based on information from management during the performance of the audit. Despite all that, the auditor's responsibility for the financial statements he or she has audited still remains confined to the expression of his or her opinion on them.

The primary responsibility for prevention and detection of financial irregularities and errors according to ISA 240 rests with management because it has a contractual duty of care. 
Management also has the stewardship capacity given that owners or shareholders entrust to them resources. Management is therefore expected to set up accounting and internal control systems that protect the assets by timely preventing and detecting financial irregularities and fraud, ensure sound financial management of revenues and expenditures, and help them show proof of transparency and accountability as those entrusted with property to manage on behalf of others. Although auditors are not beholden to assist the management in this task, the auditing guidelines require them to remind management of such a responsibility. Such a reminder usually comes in the auditor's engagement letter with the organisation.

Interaction with some stakeholders of microfinance institutions in Cameroon indicate the prevalence of occupational fraud in general and financial fraud in particular in some of these institutions. Some complained of poor accountability and transparency in the management of the resources placed at their disposal. All this left the researcher with the research questions:

a) What are the financial statement fraud likelihood determinants in micro financial institutions in Cameroon?

b) What measures can be taken to mitigate financial statement fraud?

Consequently, the main objective of the study was to examine the likelihood determinants of financial statement fraud in selected micro financial institutions in Cameroon. The specific objectives were to:

a) Investigate the financial statement fraud schemes in microfinance institutions in Cameroon

b) Conceive measures to mitigate financial statement fraud in micro financial institutions in Cameroon

The rest of the paper is structured to give a review of related literature, the methodology to examine the financial statement fraud likelihood, an interpretation of the results, policy implications and a conclusion.

\section{LITERATURE REVIEW}

The conceptual literature reviews the concepts of error and fraud, financial statement fraud, internal control, and microfinance institution.

Millichamp (1997) describes errors as unintentional mistakes which may occur at any stage of the business transaction. This implies an error is a misstatement in financial statements, including the omission of an amount or a disclosure, a mistake in gathering or processing data from which financial statements are prepared, an incorrect accounting estimate arising from oversight or misinterpretation of facts, and a mistake in the application of accounting principles relating to measurement, recognition, classification, presentation or disclosure. On the other hand, fraud refers to an intentional act by one or more individuals among management, those charged with governance, employees, or third parties, involving the use of deception to obtain an unjust or illegal advantage.

For fraud to attract the attention of the auditor, it must be that which caused a material misstatement in the financial statements. A material misstatement is information in the financial statements that is sufficiently incorrect that it may impact the economic decisions of someone relying on those statements (Accounting Tools, 2018). A misstatement 
may result from fraudulent financial reporting or from misappropriation of assets. According to ISA 240 fraudulent financial reporting may be accomplished by manipulation, falsification (including forgery), or alteration of accounting records or supporting documentation from which the financial statements are prepared; misrepresentation in, or intentional omission from, the financial statements of events, transactions or other significant information; and intentional misapplication of accounting principles relating to amounts, classification, manner of presentation, or disclosure. In line with ISA 240, Wells (2017) orates that fraudulent financial reporting includes intentional misstatements involving omissions of amounts or disclosures in financial statements to deceive users of financial statements. Wells then defined fraudulent financial reporting or financial statement fraud as deliberate misstatements or omissions of amounts or disclosures of financial statements to deceive financial statement users, particularly investors and creditors.

Fraudulent financial reporting is sometimes conceived through fraudulent audit confirmations. Fraudulent audit confirmations are concerned with accounts or transactions that are confirmed with third parties (sales, cash, accounts receivables, debt, liabilities, etc.). Generally collusion with third parties takes place. They may involve the company providing the auditors with false contact information such as false mailing addresses and phone numbers so that confirmations are diverted to co-conspirators implicated in the fraud scheme (Deloitte, 2009). However, Audit standards require that an auditor maintains control of the confirmation process from start to finish. An auditor or investigator is not expected to take as audit evidence a statement or piece of paper provided by the client without autonomously authenticating that information. Control and professional scepticism should be the forefront front (Confirmation, 2010). Professional scepticism measured as auditor's assessment of the truthfulness of the client

According to Pinkasovitch (2019) financial statement fraud red flags usually come up when a firm experiences accounting anomalies where sales and cash inflow do not move in tandem as revenues increase without a corresponding growth in cash flows; where sales grow consistently while reputable competitors are experiencing poor sales; when the company experiences immense pressure to meet analysts' expectations and there is a noteworthy rise in the company's performance within the reporting financial year; where there is a weak internal control system and corporate governance, and where management compensation is based on bonuses generated from short term targets, the incentive to commit fraud increases. Instruments such as Beneish model can be used to detect financial statement fraud. Its effectiveness has been proven to reach $89.5 \%$ on USA companies' data (Feruleva and Shtefan, 2017).

The primary responsibility for prevention and detection of irregularities and errors rests with management because it has a contractual duty of care. In this respect, the management puts up an internal control system. The Oxford dictionary of accounting defines internal control as a system of controls, both financial and nonfinancial, set up by the management of a company to carry out the business of the company in an orderly and efficient manner. Such a system ensures that management policies are adhered to, assets safeguarded, and the assets of the company's activities are both complete and accurate. An internal control system comprises many individual internal controls. 
An auditor conducting an audit in accordance with ISAs has the obligation to obtain reasonable assurance that the financial statements taken as a whole are free from material misstatement, whether caused by fraud or error. Arens and Loebbecke, 1994 opine that fraudulent financial reporting is a violation of accounting standards regarding the omission of existing figures or the inclusion of fictitious figures. Financial statement fraud negatively affects direct cost, employees, and investors, and undermines the reliability of corporate financial reporting which result in higher transaction costs and less efficient markets (Perols, 2011).

Fraudulent financial reporting is defined by the Association of Certified Fraud Examiners (ACFE) as the intentional, deliberate, misstatement or omission of material facts, or accounting data to mislead and, when considered with all the information made available, would cause the reader to alter his or her judgment in making a decision, usually with regards to investments (Dalnial et al., 2014).

Another concept reviewed is internal control and internal control system. Oxford Dictionary of Accounting, (2010) defines internal control as "the measures an organisation employs to ensure that opportunities for fraud or misfeasance are minimised. Examples range from requiring more than one signature on certain documents, security arrangements for stock handling, division of tasks, keeping of control accounts, use of special passwords, handling of computer files ..." It defines an internal control system as "a system of controls, both financial and non-financial, set up by the management of a company to carry out the business of the company in an orderly and efficient manner. The system should ensure that management policies are adhered to, assets are safeguarded, and the records of the company's activities are both complete and accurate". Internal auditors are expected to ensure that the internal controls work the way they were designed to work in order that the external auditors can have faith in the accounts produced by the organisation, and also assure management of the integrity of its operations. In a nutshell, an auditor may place reliance on an internal control if he has ascertained and evaluated the controls, and performed compliance tests on their operations (Millichamp 1997).

Microfinance institutions in the CEMAC region since 2002 are organised and supervised based on law $\mathrm{n}^{\circ}$ 01/02/CEMAC/IMAC/COBAC. Its article 1 defines microfinance as "activities undertaken by authorised entities that are neither banks nor financial institutions but take savings or deposits, give out credits or loans and offer specific financial products to those generally excluded from banking networks". The text categorises microfinance institutions in 3. Category one comprises institutions that collect savings and deposits and lend them exclusively to their members. Examples are associations, cooperatives and credit unions. This category has no clearly defined capital although the regulations require the capital to meet up with the prudential norms.

Category two financial institutions collect savings and deposits and lend them to third parties. Examples are limited liability companies that function more like micro-banks. They have a minimum capital 50 million F.CFA. Category 3 comprises lending institutions that do not collect savings and deposits but give out loans. They have a minimum capital of 25 million F.CFA. They include micro credit and project finance institutions. Both categories 2 and 3 finance institutions when applying for accreditation must show proof of an account with the 
stipulated capital in a commercial bank. This categorisation places the Cameroon microfinance institutions overtly in category one.

Three theories were reviewed namely agency, fraud triangle, and fraud diamond theories. The agency theory comes to play whenever one party is paid by another to render a service, thus making the two parties to be in a relationship albeit both parties have different interests and asymmetric information. The owners of the organisation are the principal while the managers are the agents (Donaldson and Davis, 1991; Guangdi and Fulwood, 2013). This relationship usually results in a principal-agent problem known as agency dilemma, where it becomes difficult to encourage the agent to act in the best interests of the principal (Lucian and Jesse, 2004).

The fraud triangle and diamond theories bring out the fraud risk factors by showcasing the events or conditions that indicate an incentive or pressure to commit fraud or provide an opportunity to commit fraud. The fraud triangle theory came up in 1950, when Donald Cressey, a criminologist, started the study of fraud by arguing that there must be a reason behind everything people do (Abdullahi et al., 2015). Worried about why people commit fraud Cressey carried out a study in which he interviewed some 200 embezzlers imprisoned and came out with the conclusion that every fraud had 3 things in common namely: pressure (sometimes referred to as motivation, or incentive), rationalisation (that is, reasons to justify), and knowledge and opportunity to commit the crime.

Cressey (1953) identified that pressure may come to bear on management or any staff to commit fraud because of insatiable greed, habits (such as drugs, women, and gambling), and psychosis. He then came out with a fraud triangle which still remains prominent in explaining why fraud is committed. Opportunity to commit fraud comes up when there are cracks in the internal control system, and the culprits have knowledge of the weaknesses in the controls. However, motivation and opportunities are interactive. For example, the greater the weakness in controls, the less the level of motivational need sufficient to commit a fraud.

The third theory reviewed was the fraud diamond theory. It was first presented by Wolfe and Hermanson (2004), and is commonly beheld as an extension of the fraud triangle theory. The fraud diamond theory introduces an element termed capability to the three initial fraud elements of the fraud triangle theory. Capability refers to the ability to do something (Mirriam-Webster Dictionary). According to Abdullahi et al., (2015) Wolfe and Hermanson (2004) argued that although perceived pressure or incentive might coexist with an opportunity to commit fraud and a rationalisation for doing so, it is unlikely for fraud to take place unless the fourth element known as capability is also available. The elements of the fraud diamond theory namely, pressure, opportunity, rationalisation, and capability are interrelated such that unless all the elements are present fraud cannot be committed.

Results of a research carried out and excerpts published in his book: The thief in the white collar, Norman (1960) urged employers who want to avoid employee fraud, theft and embezzlement to pay employees fairly, treat employees decently, and listen to employee problems. However, he cautions employers not to place full trust in neither the employees nor security persons hired to check on employees. Disagreeing with Jaspan's generalisations, Hartung rather argued that violators of financial trust and career delinquents both 
systematically learn from the environment. It would appear both researchers are correct as one needs to create an environment with few reasons and with few opportunities to commit fraud (Singleton, 2010).

In a study carried out by Rahmana and Anwar (2014) to examine the effectiveness of fraud prevention and detection techniques in Malaysian Islamic banks, it was realised that no matter how hard an organisation tries to deter and curb fraud, it will always occur. They concluded that the creation of awareness among employees on fraudulent activities and the solutions engaged to avoid and detect them would constitute a substantial solution for fraud. They recommended all the components of deterrence, prevention, detection, mitigation, analysis, policy, investigation and prosecution to be simultaneously implemented as delineated under the Fraud Management Lifecycle Theory in order to effectively prevent and detect fraud within banks.

The report to the nations by AFCE (2018) revealed that 2,690 real cases of occupational fraud recorded in 125 countries in 23 categories of industries caused a total loss of $\$ 7$ billion. Financial statement fraud schemes were the least common, $10 \%$ of cases, yet most costly. Small businesses lost almost twice as much per fraud scheme, $\$ 104,000$ median loss. Concerning detection methods, tips constituted $40 \%$ detection method, internal audit, 15\%, and management review, 13\%. Internal control weaknesses were responsible for nearly half of frauds. All 18 anti-fraud controls analysed were associated with lower fraud losses and quicker detection. Data monitoring/analysis and surprise audits were correlated with the highest reduction in fraud and loss duration, yet only $37 \%$ of victim organisations implemented these controls. The report further revealed that over the past 10 years, occupational fraud referrals to prosecution declined by $16 \%$ for fear of negative publicity. Fraudsters who had been with their company longer stole twice as much. Owners and executives account for a small percent of cases, 19\%, yet caused a high median loss of $\$ 850,000$. Losses caused by men were $75 \%$ larger than those caused by women; and median losses are far greater when there is collusion. In examining how occupational fraud is committed in government agencies financial statement fraud schemes accounted for $6 \%$ of government fraud cases and had a median loss of USD 315,000.

In a study carried out in the banking sub sector and the public service in Nigeria by Nenyiaba and Okoye (2015), it was revealed that there is significant relationship amongst Accounting Standards, Corporate Governance and Internal Controls in determining how free financial statements are from fraud in Nigeria. It further disclosed that auditor's independence, whistle blowing and level of education of accountants received little or no attention.

Financial analysis tools used to determine the likelihood of fraud in financial statement include financial Leverage proxies by total debt and total equity ratios, profitability proxies by net profit to revenue, asset Composition represented by current asset to total asset, receivables to revenue, inventory to total asset (Subramanyam and Wild, 2009). Current assets such as account receivables and inventories are more disposed to manipulation (Liou and Yang 2008, and Spathis, 2002) 


\section{METHODOLOGY}

The study was conducted for the period 2013 to 2018 in Cameroon. Cameroon is a country in Central Africa that shares boundaries with Nigeria to the west and north; Chad to the northeast; Central African Republic to the east; and Equatorial Guinea, Gabon and the Republic of the Congo to the south. Geographically and historically Cameroon, though not in ECOWAS is located in West Africa. Sometimes Cameroon is identified as a West African country, and other times as Central African country due to its strategic position at the crossroads between West and Central Africa. Cameroon has over 240 native languages spoken by over 20 million people. Cameroon is a country with several major towns, with Yaounde being the political capital, and Douala the economic capital (Presidency of the Republic, 2019).

An online survey was opened to 110 certified fraud examiners and auditors who have audited and or investigated micro financial institutions in Cameroon for the period 2010 to 2018 to give their experiences of how financial statement fraud was committed in these microfinance institutions. 103 respondents successfully filled the questionnaire giving a response rate of 93.6\%. In the questionnaire, the respondents were asked to rank each parameter under examination based on the level of importance that they attached to each of the items listed. A psychometric response scale called Likert scale was used in the questionnaire to get the participant's answer or agreement with each statement. In the rating (5) indicated very strong, (4) = strong, (3) = fairly strong, $(2)=$ weak and (1) = very weak.

The test of reliability was carried out using the Cronbach's alpha and Split-Half Coefficients which are measures of internal consistency. Jarque-Bera normality test was used to test whether the data followed the normal distribution or not. It is a goodness-of-fit test that shows whether sample data have the skewness and kurtosis that matches a normal distribution. If the test statistic is far from zero, it signals that the data do not have a normal distribution. In general the test is always nonnegative. VIF were applied to test for presence of multicollinearity. A model was therefore conceived as follows:

$\mathrm{FSFS}=\mathrm{B}+\mathrm{FAC}+\mathrm{FS}+\mathrm{AAR}+\mathrm{MR}+\mathrm{IMAP}+\mathrm{BR}+\mathrm{ICE}$

The economic expression is as follows:

$\mathrm{FSFS}_{\mathrm{i}}=\beta 0+\beta 1 \mathrm{FACi}+\beta 2 \mathrm{FSi}+\beta 3 \mathrm{AARi}+\beta 4 \mathrm{MRi}+\beta 5 \mathrm{IMAPi}+\beta 6 \mathrm{BRi}+\beta 7 \mathrm{ICEi}+\lambda \mathrm{i} \ldots .(2)$ Where:

$\beta 0=$ Intercept $, \beta 1, \beta 2, \beta 3, \beta 4 \ldots \beta 7=$ Parameters coefficients to be estimated for the variables in the regression equation, $\lambda=$ Error or disturbance term with its assumed normality, FSFS = Financial statement fraud schemes, $\mathrm{FAC}=$ Fraudulent Audit Confirmations, $\mathrm{FS}=$ Falsifications, AAR $=$ Alteration of accounting records, $\mathrm{MR}=$ Misrepresentation, $\mathrm{IMAP}=$ Intentional misapplication of accounting policies, $\mathrm{BR}=$ Bid rigging, $\mathrm{ICE}=$ Improper capitalisation of expenses.

Table 3.1 presents Cronbach's Alpha coefficient. From the results shown, the value of the Cronbach's alpha coefficient is high for financial statement Fraud Schemes (0.7659), while it is low for improper capitalisation of expenses (0.5474). Thus, the questionnaire gave the researcher an assurance of its reliability and validity. It gave the truth and suitability to 
analyse the results and to answer questions of the study and testing of hypotheses. The data generated was then tested for normality using Jarque-Bera normality test.

Table 3.1 Cronbach's Alpha coefficient and Split-Half Coefficient

\begin{tabular}{llll}
\hline SN & Variable & $\begin{array}{l}\text { No. of } \\
\text { items }\end{array}$ & Cronbach's Alpha \\
\hline 1 & Financial statement fraud schemes (FSFS) & 5 & 0.7659 \\
2 & Fraudulent audit confirmations (FAC) & 7 & 0.6172 \\
3 & Falsifications (FS) & 10 & 0.6776 \\
4 & Alteration of accounting records (AAR) & 8 & 0.6293 \\
5 & Misrepresentation (MR) & 8 & 0.6260 \\
6 & Intentional misapplication of accounting & 4 & 0.6017 \\
& policies (IMAP) & 4 & \\
7 & Bid rigging (BR) & 3 & 0.7388 \\
8 & Improper capitalisation of expenses (ICE) & 3474 \\
\hline
\end{tabular}

Source: Author's computation

\section{PRESENTATION AND DISCUSSION OF RESULTS}

The test results are shown in table 4.1. From the results, the p-value was not significant for all the variables because the value was greater than $10 \%$. This implied that the variables used in the analyses were normally distributed making the assumption of Ordinary Least Squares to be satisfied. Consequently, Ordinary Least Squares estimation technique could be used. Table 4.2 presents the characteristics of the variables that were used in the model in terms of their means, standard deviations, minimum and maximum values. The results reveal that financial statement fraud scheme (FSFS) is 4 on an average with a deviation from this average value by 0.679 . It is observed that the variable has a minimum and maximum value of 1.4 and 5 respectively. On an average, Fraudulent Audit Confirmations (FAC) is 4.07 with a deviation from this average by 0.46. Its minimum and maximum values are 2.375 and 4.857 respectively. Also, the mean value of Falsification schemes (FS) is 3.765 with a deviation from this mean by 0.448 . The minimum and maximum values of these variables are 2.636 and 4.818 respectively. It is further observed that Alteration of accounting records (AAR) is 3.83 on an average, with a deviation from this average by 0.43 . It also has a minimum and maximum value of 2.64 and 5.21 respectively. 
Table 4.1. Normality Test

\begin{tabular}{lllll}
\hline SN & Variable & $\begin{array}{l}\text { Number } \\
\text { of items }\end{array}$ & $\begin{array}{l}\text { Jacque } \\
\text { Berra }\end{array}$ & P-value \\
\hline 1 & Financial statement fraud schemes (FSFS) & 5 & 2.585 & 0.2642 \\
2 & Fraudulent Audit Confirmations (FAC) & 7 & 2.003 & 0.3421 \\
3 & Falsifications (FS) & 10 & 2.177 & 0.3367 \\
4 & Alteration of accounting records (AAR) & 8 & 4.081 & 0.130 \\
5 & Misrepresentation (MR) & 8 & 3.468 & 0.1766 \\
6 & Intentional misapplication of accounting policies & 4 & 1.501 & 0.4721 \\
& (IMAP) & & & \\
7 & Bid rigging (BR) & 4 & 2.48 & 0.2894 \\
8 & Improper Capitalization of Expenses (ICE) & 3 & 3.909 & 0.1417 \\
\hline
\end{tabular}

Source: Computed by Author

Table 4.2. Summary Statistics

\begin{tabular}{llllll}
\hline Variable & Observation & Mean & $\begin{array}{l}\text { Standard } \\
\text { Deviation }\end{array}$ & Minimum & Maximum \\
\hline FSFS & 103 & 4 & 0.6791 & 1.4 & 5 \\
FAC & 103 & 4.071949 & 0.461527 & 2.375 & 4.857143 \\
FS & 103 & 3.765049 & 0.448219 & 2.636364 & 4.818182 \\
AAR & 103 & 3.833564 & 0.432913 & 2.642857 & 5.214286 \\
MR & 103 & 4.01699 & 0.685335 & 1.5 & 5 \\
IMAP & 103 & 3.835221 & 0.555229 & 2 & 4.777778 \\
BR & 103 & 3.87767 & 0.588273 & 1.8 & 4.8 \\
ICE & 103 & 3.361997 & 0.533628 & 2 & 4.428571 \\
\hline
\end{tabular}

Source: Author's computation

The mean value of Misrepresentation (MR) is 4.02 on an average, with a deviation from the mean by 0.685 . Misrepresentation has a minimum and maximum value of 1.5 and 5 respectively. Alteration of accounting records (AAR) has an average of 3.835 with a standard deviation of 0.555. Its minimum and maximum values are 2 and 4.78 respectively. Bid rigging (BR) is 3.88 on an average with a deviation from this average value by 0.588 . It is observed that the variable has a minimum and maximum values of 1.8 and 4.8 respectively. On an average, Improper Capitalisation of Expenses (ICE) is 3.36 with a deviation from this average by 0.53 . Its minimum and maximum values are 2 and 4.4 respectively.

Table 4.3 presents the correlation results acting as pre-test for multicollinearity. It is observed that the leading diagonals of all the variables give the values 1 showing perfect collinearity between each variable and itself. It is seen that FAC, FS, AAR, MR, IMAP, BR, and ICE all have a positive relationship with financial statement fraud schemes. This positive relationship implies that an increase in the independent variables will be accompanied by an increase in the dependent variable and vice versa. Since no pair of the explanatory variables has a correlation coefficient of more than 0.8 there is no trace of multicollinearity, (Gujarati, 2004). 
Table 4.3. Correlation Results

\begin{tabular}{lllllllll}
\hline & FSFS & FAC & FS & AAR & MR & IMAP & BR & ICE \\
\hline FSFS & 1 & & & & & & & \\
FAC & $0.3856^{*}$ & 1 & & & & & \\
FS & $0.3409^{*}$ & 0.229 & 1 & & & & \\
AAR & 0.1458 & $0.3061^{*}$ & 0.2106 & 1 & & & \\
MR & 0.2201 & 0.1573 & 0.0186 & $0.2787^{*}$ & 1 & & \\
IMAP & $0.2859^{*}$ & 0.129 & $0.3859^{*}$ & $0.3305^{*}$ & 0.109 & 1 & \\
BR & 0.1806 & $0.2793^{*}$ & 0.059 & 0.1607 & $0.2946^{*}$ & -0.1011 & 1 \\
ICE & $0.2758^{*}$ & 0.1069 & -0.1636 & -0.0171 & 0.2243 & 0.1151 & 0.1514 \\
\hline
\end{tabular}

Source: Author's computation

Table 4.3 presents the correlation results acting as pre-test for multicollinearity. It is observed that the leading diagonals of all the variables give the values 1 showing perfect collinearity between each variable and itself. It is seen that FAC, FS, AAR, MR, IMAP, BR, and ICE all have a positive relationship with financial statement fraud schemes. This positive relationship implies that an increase in the independent variables will be accompanied by an increase in the dependent variable and vice versa. Since no pair of the explanatory variables has a correlation coefficient of more than 0.8 there is no trace of multicollinearity, (Gujarati, 2004).

Table 4.4 shows the VIF results which are used to further test for multicollinearity. If the VIF of a coefficient of a variable exceeds 10, then that variable is highly collinear, and multicollinearity becomes a problem (Gujarati, 2004). In this study, the VIF results show that individually, none of the VIF exceeds 10, thus it can be concluded that there is no problem of multicollinearity among the independent variables.

Table 4.4. VIF Results

\begin{tabular}{lll}
\hline Variable & VIF & 1/VIF \\
\hline IMAP & 1.61 & 0.622424 \\
AAR & 1.47 & 0.682119 \\
FS & 1.42 & 0.704082 \\
MR & 1.38 & 0.727071 \\
FAC & 1.33 & 0.75193 \\
BR & 1.27 & 0.784565 \\
ICE & 1.19 & 0.843042 \\
Mean VIF & 1.38 & \\
\hline
\end{tabular}

Source: Author's computation

\section{DISCUSSION OF RESULTS}

The results of the financial statement fraud determinants in micro financial institutions are presented in Table 5.1. The results are presented in two columns. Based on the result of the FSFS (1) equation, Fraudulent Audit Confirmations (FAC) is seen to positively affect financial statement fraud scheme as its coefficient is positive. Specifically, from the result, a unit increase in FAC fraud will increase financial statement fraud scheme by some 0.287 . The 
effect of FAC is statistically significant at the 5\% level of significance. As a remedy, auditors must have control of the confirmation process from start to finish and show professional scepticism as required by SAS 99 and AS 1015. The auditors must wear a questioning mind and a critical assessment of audit evidence notwithstanding the belief that management is truthful and should be trusted.

Table 5.1 Regression Results

\begin{tabular}{lll} 
VARIABLES & FSFS(1) & FSFS(2) \\
& & \multicolumn{1}{c}{$\begin{array}{c}\text { Coefficient } \\
\text { (Robust Standard Errors) }\end{array}$} \\
\hline & & \\
FAC & $0.287^{* *}$ & $0.248^{*}$ \\
& $(0.129)$ & $(0.133)$ \\
FS & $0.545^{* * *}$ & $0.506^{* * *}$ \\
& $(0.187)$ & $(0.141)$ \\
AAR & 0.137 & 0.132 \\
& $(0.172)$ & $(0.155)$ \\
MR & $0.191 * *$ & $0.191 * *$ \\
& $(0.0933)$ & $(0.0933)$ \\
IMAP & 0.0747 & 0.0858 \\
& $(0.159)$ & $(0.126)$ \\
BR & 0.0695 & 0.0748 \\
& $(0.104)$ & $(0.102)$ \\
ICE & $0.324 * * *$ & $0.309 * * *$ \\
& $(0.104)$ & $(0.108)$ \\
Constant & $-1.689^{*}$ & -0.935 \\
& $(0.924)$ & $(0.937)$ \\
& & \\
Observations & 101 & 101 \\
F-Test & $6.42^{* * *}$ & $5.55^{* * *}$ \\
R-squared & 0.458 & 0.479 \\
\hline
\end{tabular}

Source: Author computation
$* * *, * *, *$ Significant at $1 \%, 5 \%$, and $10 \%$ level of significance

Based on the result of the FSFS (1) equation, Fraudulent Audit Confirmations (FAC) is seen to positively affect financial statement fraud scheme as its coefficient is positive. Specifically, from the result, a unit increase in FAC fraud will increase financial statement fraud scheme by some 0.287 . The effect of FAC is statistically significant at the $5 \%$ level of significance. As a remedy, auditors must have control of the confirmation process from start to finish and show professional scepticism as required by SAS 99 and AS 1015. The auditors must wear a questioning mind and a critical assessment of audit evidence notwithstanding the belief that management is truthful and should be trusted. 
Falsification (FS) as another variable positively affects financial statement fraud scheme as its coefficient is positive. Specifically, from the result, a unit increase in FS will increase financial statement fraud scheme by about 0.545 point. The variable is statistically significant at $10 \%$ level of significance. FS is however seen to have a greater effect on financial statement fraud scheme based on FSFS (1) equation as its coefficient here is greater than in FSFS (2). Micro financial institutions should watch out against likelihood presence of falsifications when among other things there is unjustified overstatement or understatement of financial amounts compared to previous years; decrease in cash receipts when income is on the rise; excessive procurements; and a fall in accounts payable when apparently stock figures rise (Pinkasovitch, 2019; Rakutko et al., 2016).

The variable Alteration of accounting records (AAR) is seen to positively affect financial statement fraud scheme as its coefficient is positive. Specifically, from the result, a unit increase in AAR will increase financial statement fraud by about 0.137 point. However, the result is statistically insignificant as the coefficient of the variable is less than 2 times the standard error. To significantly alleviate this fraud scheme, all documentation and books such as records of assets and liabilities, journals and ledgers, and any supporting documents like checks and invoices involved in the preparation of financial reports need to undergo serious scrutiny by auditors before placing reliance on.

Misrepresentation (MR) positively affects financial statement fraud scheme as its coefficient is positive. Specifically, from the result, a unit increase in MR practice will increase financial statement fraud scheme by about 0.191 points. The variable is statistically significant in at $5 \%$ level of significance.

Intentional misapplication of accounting policies (IMAP) affect financial statement fraud scheme positively in both equations as their coefficients are positive. However, the result shows that both variables are statistically insignificant in both equations as the P-value is greater than $10 \%$.

Improper Capitalisation of Expenses (ICE) positively affects financial statement fraud scheme as its coefficient is positive. Specifically, from the result, a unit increase in ICE will increase financial statement fraud by about 0.324 . With the equation containing the nonlinear variable FSFS (2), a unit increase in ICE will also increase financial statement fraud by about 0.309 . The variable is statistically significant in both equations at $10 \%$ level of significance. However ICE is seen to have a greater effect on financial statement fraud scheme based on FSFS(1) equation as its coefficient here is greater than in FSFS(2).

Bid rigging positively affects financial statement fraud as its coefficient is positive. However, it is statistically not significant but should not be ignored in curbing financial statement fraud. Owners of micro financial institutions must put in place a control system to ensure that bids undergo due process before awarding a contract.

The coefficient of R-squared is 0.458 for the FSFS (1) equation and 0.479 for the FSFS (2) equation. This means that $45.8 \%$ and $47.9 \%$ of the variation in financial statement fraud scheme is explained by the independent variables in FSFS (1) and FSFS (2), respectively. The Goodness of fit test results based on the F-test is highly significant. This implies that the independent variables are significantly explaining the Financial Statement Fraud Scheme. It 
is important to note that the reported standard errors are robust. This robust estimation was carried out to solve for potential problems of heteroscedasticity.

\section{POLICY IMPLICATIONS AND CONCLUSION}

Likelihood determinants of financial statement frauds in micro financial institutions in Cameroon are the following fraud schemes: fraudulent audit confirmations, falsification of financial amounts, alteration of accounting records (especially those of assets and liabilities), misrepresentations, and improper capitalisation of expenses. To a lesser extent, bid rigging and intentional misapplication of accounting policies are also likelihood determinants. Although financial statement fraud cannot be completely eradicated given that they are perpetuated by human beings who themselves are imperfect, it can be significantly mitigated when micro financial institutions become conscious of the events or conditions that motivate the commission of fraud in general and financial statement fraud in particular. The literature reviewed disclosed the following: pressure, rationalisation, opportunity, and capability to commit the crime. These elements are interrelated such that unless all the elements are present fraud cannot be committed (Abdullahi et al., 2015).

MFIs are encouraged to create enabling environment for the decay of these elements by strengthening the internal control systems of assets, liabilities, expenses, and revenues. Independent audits be carried out irregularly, take actions against perpetrators of fraud, and treat employees decently and fairly. Proper education be given on financial management ethics, and management should be very sensitive to behavioural red flags.

\section{REFERENCES}

Abdullahi, R., Mansor N. and Nuhu, M.S. (2015). Fraud Triangle Theory and Fraud Diamond Theory: Understanding the Convergent and Divergent for Future Research, European Journal of Business and Management www.iiste.org ISSN 2222-1905 (Paper) ISSN 2222-2839 (Online) Vol.7, No.28, 2015

Arens and Loebbecke, J. (1994). Auditing: An Integrated Approach, 6th ed. Englewood CliFFR, New Jersey: Prentice-Hall.

Association of Certified Fraud Examiners Inc. (2018). Report to the Nations, global study on occupational fraud and abuse. Retrieved February 2019 from https://www.acfe.com/uploadedFiles/ACFE_Website/Content/rttn/2018/RTTN-AsiaPacific-Edition.pdf

Accounting Tools, https://www.accountingtools.com/articles/2018/5/19/materialmisstatement

American Institute of Certified Public Accountants

Association of Certified Fraud Examiners (2010). Report to the Nation on Occupational Fraud. Retrieved July, 2018, https://acfe.com/ documents/2010RttN.pdf

Association of Certified Fraud Examiners, (2008). Fraud examination and forensic accounting services. Retrieved July 2019 from http://www.forensicinvspec.com/

Center for Responsibility Enterprise and Trade (2018). https://create.org/news/theconsequences-of-corruption/

Cheshire Police constabulary. Retrieved March 2019 from https://www.cheshire.police.uk/advice-and-support/.../asset-misappropriation-fraud/ 
Print ISSN: 2053-4086(Print), Online ISSN: 2053-4094(Online)

COBAC, (2002). Règlement $\mathrm{N}^{\circ}$ 01/02/CEMAC/IMAC/COBAC relatif aux Conditions d'Exercice et de Contrôle de l'Activité de Microfinance dans la Communauté Economique et Monétaire d'Afrique Centrale.

Confirmation, 2010. What we need to know about confirmation fraud. Retrieved May 2019 from

https://www.cftc.gov/sites/default/files/idc/groups/public/@newsroom/documents /file/tac072612_whitepaper2.pdf

Dalnial et al. (2014). Detecting Fraudulent Financial Reporting through Financial Statement Analysis. Journal of Advanced Management Science Vol. 2, No. 1

Deloitte (2009). Sample listing of fraud schemes. Retrieved November 2019 from https://www2.deloitte.com/content/dam/Deloitte/in/Documents/risk/Corporate\%20Go

vernanc e/Audit\%20Committee/in-gc-fraud-schemes

Donaldson, L. and Davis, J. (1999): Agency Theory - Accounting practices. Retrieved August

2018 from http://www.ukessays.com /essays/finance/agencyory.php

Dictionary.com, https://www.dictionary.com/browse/fraud

European Court of Auditors (2014). Audit guideline on fraud https://www.eca.europa.eu/lists/ecadocuments/auditguideline_fraud/auditgui deline_fraud_en.pdf

Feruleva, N. V. and Shtefan M.A. 2017. Detecting financial statement fraud: statement from Russia. Journal of Corporate Finance Research. Vol. 12 |\# 2

Fonction publique : 20000 fonctionnaires fictifs au Cameroun, www.cameroon-online.com

Fotabong, L.A. (2012). The microfinance market of Cameroon: Analysing trends and current developments. $\quad$ Retrieved January 2019 from http://www.microfinancegateway.org/sites/default/files/mfg-en-paper-themicrofinance-market-of-cameroon-analyzing-trends-and-current-developments-mar2012.pdf

Guangdi, C. and Fulwood, C. (2013): An Agency Theory Approach to Sovereign Debt Crisis. The International Journal of Business and Finance Research, v. 7 (5) p. 123-134

Gujarati, D. (2004): Basic Econometrics. McGraw-Hill Companies, New York.

Kathleen, M. E. (1989): Agency theory: An assessment and Review. The Academy of management Review, Vol. 14

Liou, F. M. and Yang, C. H. "Predicting business failure under the existence of fraudulent financial reporting," International Journal of Accounting and Information Management, vol. 16, no. 1, pp. 74-86, 2008

Lucian, B. and Jessie F. (2004): Pay without Performance: The Unfulfilled Promise of Executive Compensation. Cambridge: Harvard University Press.

Millichamp, A.H. (1997). Auditing: An Introduction Manual for Accounting Students. D.P. Publications, Shepherds Bush Green, London.

Mirriam Webster Dictionary, https://www.merriam-webster.com/dictionary/fraud

Nenyiaba, I. C. and Okoye E. I. (2015). Evaluation of Key Determinants of Fraud Free Financial Report: a Focus on Nigeria. Business and Management Studies, Vol. 1, No. 2.

Oxford Dictionary of Accounting. (2010). Oxford University Press, www.oup.com

Payne, E. A. and Ramsey, R. J. (2005). Fraud risk assessments and auditors' professional scepticism. Managerial Auditing Journal, Vol. 20 No. 3, pp. 321-330. 
Pinkasovitch, A. (2019). Detecting Financial Statement Fraud. Retrieved August 2019 from https://www.investopedia.com/articles/financial-theory/11/detecting-financialfraud.asp

Presidency of the Republic of Cameroon (2019). Cameroon. Retrieved March 2019 from https://www.prc.cm

Public Company Accounting Oversight Board (PCAOB, 2017). Auditing Standards. Retrieved January 2019 from https://pcaobus.org/Standards/Auditing/Documents/PCAOB_Auditing_Standards_as_ of_December_15_2017.pdf

Rahman, R. A. and Anwar, I. S. K. (2014). Effectiveness of fraud prevention and detection techniques in Malaysian Islamic banks. Procedia - Social and Behavioral Sciences 145 (2014) 97 - 102.

Rakutko, S. Y., Berezhnova, E. I., Selezneva, E. Y., Belik, E. V., Shalaeva, N. I., Denisevich, E. I., Belik, N. V., Saenko, Z.E., Sultanova, A. A., (2016). Issues of Falsifying Financial Statements in terms of Economic. International Journal of Environmental and Science Education 2016, Vol. 11, No. 17, 10163-10176

Singleton, T.W. (2010). Fraud Auditing and Forensic Accounting. Retrieved November 2018 from https://books.google.cm/books?isbn=047056413X

Subramanyam, K. and Wild, J. J. (2009). Financial Statement Analysis, 10th ed. New York: McGraw Hill

Thomas Gerrard and Sons Limited case, 1967. Retrieved in January 2019 from https://www.coursehero.com/file/p41kctc/Kingston-Cotton-Mill-No-2-1896-In-ReThomas-Gerrard-Son-Ltd-1968-the-Company/

Transparency International, https://www.transparency.org/what-is-corruption International on Standards Auditing. http://www.ifac.org/system/files/downloads/2008_Auditing_Handbook_A080_ISA_2 40.pdf

Investopedia, https://www.investopedia.com/terms/c/corruption.asp

Norman, J. (1960). The thief in the white collar. Retrieved July 2018 from https://www.abebooks.co.uk/book-search/title/the-thief-in-the-whitecollar/author/norman- jaspan

Schuchter, A. and Levi, M. (2013). The fraud triangle revisited. Retrieved February 2019 from https://www.researchgate.net/publication/271270579_The_Fraud_Triangle

Spathis, C. (2002). "Detecting false financial statements using published data: Some evidence from Greece," Managerial Auditing Journal, vol. 17, no. 4, pp. 179-191.

McNeil, I. (1992), "Ruling out an academic argument," The Times, pp. 27, March 26, 1992.

Wells, J. T. (2017). Financial statement fraud schemes. Retrieved August 2019 from https://onlinelibrary.wiley.com/doi/10.1002/9781119351962.ch13 